\title{
Trends in Working Capital Management and Evidences of Zero Working Capital: An Empirical Investigation in SAIL and TSL
}

\author{
R. Rajamani ${ }^{1 *}$, S. Harini ${ }^{2}$ and A. Gomathi ${ }^{2}$ \\ 'Associate Professor, PG \& Research Department of Commerce, Vellalar College for Women, \\ Erode, India; rajamani.commerce@gmail.com \\ ${ }^{2}$ Final M.Com, Vellalar College for Women, Erode, India
}

\begin{abstract}
The manufacturing companies subjected to operating cycle aim at shorter conversion cycle, so that working capital requirements are managed spontaneously without tapping external sources. It is in this context the concept of zero working capital is gaining momentum. Hence an attempt has been made in the present study to observe between the sample companiesSAIL and TSL the trends in liquidity management; trends in percentage share of individual components in the total current assets; and whether the strategy of zero working capital has been adopted and further its impact on profitability. The study covers a period of ten years from 2005-06 to 2014-15, of which the first five years (2005-06 to 2009-10) were taken as phase I and the second five years (2010-11 to 2014-15) were taken as Phase II and the data of these two sets stand independent. For the purpose of analysis relevant accounting ratios, descriptive statistics, correlation and regression coefficients were computed. Null hypotheses were set and ' $t$ ' and ' $F$ ' tests were applied to draw conclusion. The study has divulged that unlike SAIL, TSL was adopting zero working capital consistently throughout the study period and has impacted significantly on the variability of its Return on Capital Employed. This, however, could be continued without straining the relationship with creditors.
\end{abstract}

Keywords: Cash Conversion Cycle, Zero Working Capital, Zero Working Capital Ratio

\section{Introduction}

Sound financial health of an organization basically emerges from the effective and efficient management of working capital. Management of working capital focuses on the risk-return trade-off involved in holding the current assets [1], since both excessive and inadequate investment in current assets should be avoided. It is in this context, that the zero working capital strategy is gaining momentum among business firms, particularly capital intensive manufacturing firms, which aim at level playing to make the operational current assets (inventory and receivables) equal to current liabilities. This however, calls for a minimum or short conversion period of inventories and receivables, while the account payable period needs to be at the maximum possible, without affecting the confidence of the creditors.
Hence, this paper probes the trends in working capital management of the firms in the steel industry, that are capital intensive constituting the core manufacturing sector which however are facing a threat of stiff competition in the recent years since the market is flooded by cheaper imports of steel and steel products from China [2].

\section{Review of Literature}

An insight into the earlier researches of the past in this context has enabled to identify the research gap, for it has exposed the following:

Eljelly [3] confirmed that the cash conversion cycle or the cash gap is a prominent measure of liquidity which affects profitability, especially in case of capital-intensive firms in Saudi Arabia. Padachi [4] exposed a strong significant

*Author for correspondence 
relationship between cash conversion cycle and profitability of the firms. Gill, Biger and Mathur [5] brought to the fore a significant relationship between cash conversion cycle and profitability. Niranjan Mandan et al. [6] concluded that different components of working capital impact the profitability differently. Abdul Raheman et al. [7] asserted that cash conversion cycle influenced the performance of the organization. Jain P.K. et al. [8] affirmed the adoption of the concept of zero working capital by the firm of their study. Bana Abuzayed [9] found that cash conversion cycle positively affected the profitability of the firms. Daniel Mogaka Makori and Ambrose Jagongo [10] stated that by reducing the cash conversion cycle to its minimum, firms can increase their profitability. Naveen Ch. [11] found that the company of his study had consistently adopted zero working capital, but only in four out of ten years of the study period.

However, the present study deviates from the earlier researches, for it aims to determine the trends in both the liquidity management and in the components constituting the total current assets in respect of the select firms. Further, the study intensively focuses on to determine whether the select firms have adopted the strategy of zero working capital and its impact on profitability.

\section{Objectives of the Study}

- To perceive the trends in liquidity management of the select firms.

- To observe the trends in percentage share of the components constituting the total current assets.

- To determine whether the select firms have adopted the concept of zero working capital and its impact on profitability.

\section{Methodology}

The study covers a period of ten years from 2005-06 to 201415 , of which the first five years (2005-06 to 2009-10) were taken as phase I and the second five years (2010-11 to 201415) were taken as phase II in order to observe the trend in working capital management practices during the study period and the data of these two sets stand independent. Convenience sampling method was adopted in choosing the companies of steel industry of India. However, for the purpose of comparison between the public sector and private sector firms-Steel Authority of India Limited (SAIL) and the long standing private sector firm - Tata Steel Limited (TSL) were purposively chosen. The study is based on secondary data obtained from the published annual accounts of profit and loss account and balance sheet of the select companies, which were regrouped to facilitate the analysis.

\subsection{Tools of Analysis}

- To analyze the liquidity management of the select firms of steel industry, the ratio analysis technique, particularly liquidity ratios based on both the balance sheet approach and the operating cycle approach was employed [12].

- To analyze the trend in liquidity management and also the trend in percentage share of components constituting the total current assets, the descriptive statistics like, mean and standard deviation were computed [13].

- To confirm the concept of zero working capital, the zero working capital ratio was determined [14].

- ' $\mathfrak{t}$ '-test was applied for testing the difference between the means of two phases of data employed for the study, wherein the two sets stand independent [15].

- To analyze the impact of zero working capital on profitability, simple correlation and regression coefficients were computed along with the ' $t$ ' and ' $F$ ' values for their significance [16].

\subsection{Hypotheses Testing}

Ho1: There is no significant difference in the liquidity ratios of the firms in the second phase.

Ho2: There is no significant difference in the percentage share of the components out of the total current assets of the firms in the second phase.

Ho3: There is no significant relationship between zero working capital and profitability in respect of the sample companies.

\section{Trends in Liquidity Management}

The liquidity position and its trend in SAIL and TSL during the study period have been probed through the following liquidity ratios:

i. Current Ratio (CR)

ii. Quick Ratio (QR)

iii. Inventory Turnover Ratio (ITR)

iv. Debtors' Turnover Ratio (DTR)

v. Creditors' Turnover Ratio (CTR)

vi. Cash Conversion Cycle (CCC)

To observe the trend in liquidity position of the companies, the study period of ten years has been divided into two sets - first five years from 2005-06 to 2009-10 as I phase and the second five years from 2010-11 to 2014-15 as II phase. The data of these two sets are independent as regards all the liquidity ratios employed and the results are shown in Table 1. 
The six liquidity ratios employed to study the trends in liquidity management of SAIL and TSL during the study period as shown in Table 1 have revealed the following:

In case of Current Ratio, both SAIL and TSL had not maintained the standard norm of 2:1 [17]. The mean current ratio had declined from 1.68 during the first phase to 1.46 during the second phase in case of SAIL, which the same in case of TSL had declined from 1.70 during the first phase to 0.91 during the second phase. However, the t-test confirmed the non-significance of the difference in the second phase in respect of the both the companies.

The Quick Ratio was not satisfactory for both SAIL and TSL, particularly during the second phase, since the standard norm of 1:1 [18] was not maintained. The mean quick ratio of SAIL had decelerated from 1.22 in the first phase to 0.81 in the second phase and similarly for TSL, the same had slipped from 1.42 in the first phase to 0.64 in the second phase. The difference in the second phase in case of both SAIL and TSL was non-significant as confirmed by the $\mathrm{t}$-test.

The mean Inventory Turnover Ratio had also declined during the second phase of the study period in case of both SAIL and TSL, which the t-test confirmed to be statistically significant for both the firms.

On the score of Debtors' Turnover Ratio, SAIL had registered a deceleration during the second phase by dipping to 10.24 times the mean ratio from that of 14.40 times in the first phase, which the t-test confirmed to be statistically significant. Whereas, TSL had registered a superior performance since the mean ratio had glided up to 56.78 times during the second phase from that of 35.62 times in the first phase, which however was not statistically significant as revealed by the $\mathrm{t}$-test.

The Creditors' Turnover Ratio was not satisfactory for both SAIL and TSL as it was very low and dwindling further during the second phase, which the t-test confirmed to be statistically significant for the both the firms.

Table 1. Liquidity ratios of SAIL and TSL for the period from 2005-06 to 2014-15

\begin{tabular}{|c|c|c|c|c|c|c|c|c|c|c|c|c|}
\hline \multirow[t]{2}{*}{ Year } & \multicolumn{2}{|c|}{$\begin{array}{c}\text { CR } \\
\text { (Proportion) }\end{array}$} & \multicolumn{2}{|c|}{$\begin{array}{c}\mathrm{QR} \\
\text { (Proportion) }\end{array}$} & \multicolumn{2}{|c|}{$\begin{array}{c}\text { ITR } \\
\text { (Times) }\end{array}$} & \multicolumn{2}{|c|}{$\begin{array}{c}\text { DTR } \\
\text { (Times) }\end{array}$} & \multicolumn{2}{|c|}{$\begin{array}{c}\text { CTR } \\
\text { (Times) }\end{array}$} & \multicolumn{2}{|c|}{$\begin{array}{c}\text { CCC } \\
\text { (Days) }\end{array}$} \\
\hline & SAIL & TSL & SAIL & TSL & SAIL & TSL & SAIL & TSL & SAIL & TSL & SAIL & TSL \\
\hline 2005-06 & 1.23 & 0.72 & 0.82 & 0.41 & 2.67 & 2.30 & 14.88 & 26.99 & 1.89 & 0.69 & -31 & -357 \\
\hline 2006-07 & 1.59 & 1.77 & 1.09 & 1.49 & 2.48 & 2.52 & 16.36 & 29.81 & 2.01 & 0.76 & -13 & -324 \\
\hline 2007-08 & 1.73 & 3.92 & 1.29 & 3.65 & 2.49 & 2.44 & 14.90 & 33.45 & 2.02 & 0.67 & -9 & -382 \\
\hline 2008-09 & 1.82 & 0.97 & 1.30 & 0.68 & 2.60 & 2.72 & 14.43 & 41.29 & 2.50 & 0.79 & 20 & -318 \\
\hline 2009-10 & 2.04 & 1.12 & 1.59 & 0.86 & 2.06 & 2.59 & 11.41 & 46.58 & 1.59 & 0.70 & -22 & -373 \\
\hline 2010-11 & 1.97 & 1.55 & 1.39 & 1.31 & 2.08 & 2.18 & 11.11 & 68.45 & 1.65 & 0.55 & -13 & -490 \\
\hline 2011-12 & 1.49 & 0.93 & 0.82 & 0.69 & 1.87 & 2.20 & 10.39 & 51.10 & 1.73 & 0.55 & 20 & -496 \\
\hline $2012-13$ & 1.42 & 0.86 & 0.68 & 0.61 & 1.43 & 2.38 & 9.71 & 44.91 & 1.58 & 0.61 & 62 & -435 \\
\hline 2013-14 & 1.23 & 0.57 & 0.62 & 0.32 & 1.44 & 2.22 & 9.43 & 53.21 & 1.27 & 0.57 & 4 & -471 \\
\hline 2014-15 & 1.19 & 0.62 & 0.55 & 0.27 & 1.20 & 1.99 & 10.54 & 66.21 & 1.05 & 0.63 & -9 & -388 \\
\hline Minimum & 1.18 & 0.57 & 0.55 & 0.27 & 1.20 & 1.99 & 9.43 & 26.99 & 1.05 & 0.55 & -31 & -496 \\
\hline Maximum & 2.04 & 3.92 & 1.59 & 3.65 & 5.67 & 2.72 & 16.36 & 68.45 & 2.50 & 0.79 & 62 & -318 \\
\hline $\begin{array}{l}\text { Mean- } \\
\text { Phase I }\end{array}$ & 1.68 & 1.70 & 1.22 & 1.42 & 2.46 & 2.51 & 14.40 & 35.62 & 2.00 & 0.72 & -11 & -351 \\
\hline $\begin{array}{l}\text { Mean- } \\
\text { Phase II }\end{array}$ & 1.46 & 0.91 & 0.81 & 0.64 & 1.60 & 2.19 & 10.24 & 56.78 & 1.46 & 0.58 & 13 & -456 \\
\hline $\begin{array}{l}\text { Total } \\
\text { Mean }\end{array}$ & 1.57 & 1.30 & 1.02 & 1.03 & 4.06 & 2.35 & 12.32 & 46.02 & 1.729 & 0.65 & 0.9 & -405 \\
\hline $\begin{array}{l}\text { SD-Phase } \\
\text { I }\end{array}$ & 0.301 & 1.300 & 0.285 & 1.309 & 0.237 & 0.158 & 1.821 & 8.143 & 0.328 & 0.051 & 19.300 & 28.718 \\
\hline $\begin{array}{l}\text { SD-Phase } \\
\text { II }\end{array}$ & 0.312 & 0.391 & 0.338 & 0.416 & 0.360 & 0.139 & 0.672 & 10.137 & 0.286 & 0.036 & 30.376 & 44.850 \\
\hline $\mathrm{t}$-value & 1.146 & 1.308 & 2.053 & 1.266 & $4.442^{* *}$ & $3.405^{* *}$ & $4.793^{* *}$ & -3.638 & $2.804^{*}$ & $5.019^{* *}$ & -1.479 & $4.417^{* *}$ \\
\hline
\end{tabular}


Cash Conversion Cycle exposed a spontaneous management of working capital requirements by both SAIL and TSL, as it was negative totally in six years for SAIL and in all the years for TSL. Consequently, the mean ratio had risen from - 11 days in the first phase to 13 days in the second phase for SAIL, which however was not statistically significant as confirmed by the t-test. On the other hand, the mean cash conversion cycle for TSL had drastically declined to touch -456 days during the second phase from that of -351 days during the first phase, which the t-test confirmed to be statistically significant.

\section{Trends in Components of Current Assets}

The components constituting gross working capital or otherwise the total current assets are quite important in enabling a firm to experience an efficient working capital management. Hence an attempt has been made to bring out the trends in percentage share of individual components of current assets in the total current assets of the sample companies and the same are shown in Table 2 and 3.

Table 2. Components of current assets as a percentage of total current assets (SAIL) for the period from $2005-06$ to $2014-15$ (Rs. in crores)

\begin{tabular}{|c|c|c|c|c|c|c|}
\hline Year & $\begin{array}{c}\text { Cash \&Bank } \\
\text { Balance }\end{array}$ & $\begin{array}{c}\text { Other Bank } \\
\text { Deposits }\end{array}$ & $\begin{array}{l}\text { Sundry } \\
\text { Debtors }\end{array}$ & Inventory & $\begin{array}{l}\text { Current Loans } \\
\text { \&Advances }\end{array}$ & $\begin{array}{c}\text { Total Current } \\
\text { Assets }\end{array}$ \\
\hline 2005-2006 & $\begin{array}{l}341.83 \\
(1.82)\end{array}$ & $\begin{array}{l}5830.81 \\
(31.03)\end{array}$ & $\begin{array}{l}1881.73 \\
(10.02)\end{array}$ & $\begin{array}{c}6210.06 \\
(33.05)\end{array}$ & $\begin{array}{l}4524.37 \\
(24.08)\end{array}$ & $\begin{array}{c}18788.80 \\
(100)\end{array}$ \\
\hline 2006-2007 & $\begin{array}{l}437.36 \\
(2.02)\end{array}$ & $\begin{array}{l}9172.47 \\
(42.32)\end{array}$ & $\begin{array}{c}2314.75 \\
(10.67)\end{array}$ & $\begin{array}{l}6651.47 \\
(30.69)\end{array}$ & $\begin{array}{c}3097.70 \\
(14.29)\end{array}$ & $\begin{array}{c}21673.75 \\
(100)\end{array}$ \\
\hline 2007-2008 & $\begin{array}{r}470.17 \\
(1.72)\end{array}$ & $\begin{array}{c}13289.27 \\
(48.66)\end{array}$ & $\begin{array}{c}3048.12 \\
(11.16)\end{array}$ & $\begin{array}{c}6857.23 \\
(25.11)\end{array}$ & $\begin{array}{c}3644.22 \\
(13.34)\end{array}$ & $\begin{array}{c}27309.01 \\
(100)\end{array}$ \\
\hline 2008-2009 & $\begin{array}{l}347.94 \\
(0.98)\end{array}$ & $\begin{array}{c}17880.59 \\
(50.13)\end{array}$ & $\begin{array}{c}3024.36 \\
(8.48)\end{array}$ & $\begin{array}{c}10121.45 \\
(28.38)\end{array}$ & $\begin{array}{l}4292.50 \\
(12.03)\end{array}$ & $\begin{array}{c}35666.84 \\
(100)\end{array}$ \\
\hline 2009-2010 & $\begin{array}{r}230.76 \\
(0.58)\end{array}$ & $\begin{array}{c}22205.61 \\
(55.36)\end{array}$ & $\begin{array}{c}3493.90 \\
(8.71)\end{array}$ & $\begin{array}{c}9027.46 \\
(22.51)\end{array}$ & $\begin{array}{l}5155.32 \\
(12.85)\end{array}$ & $\begin{array}{l}40113.05 \\
\quad(100)\end{array}$ \\
\hline 2010-2011 & $\begin{array}{l}143.99 \\
(0.37)\end{array}$ & $\begin{array}{c}17334.87 \\
(44.31)\end{array}$ & $\begin{array}{l}4161.30 \\
(10.64)\end{array}$ & $\begin{array}{c}11302.79 \\
(28.89)\end{array}$ & $\begin{array}{l}6175.81 \\
(15.79)\end{array}$ & $\begin{array}{c}39118.76 \\
(100)\end{array}$ \\
\hline 2011-2012 & $\begin{array}{c}6415.70 \\
(21.05)\end{array}$ & --- & $\begin{array}{l}4761.32 \\
(15.62)\end{array}$ & $\begin{array}{c}13742.37 \\
(45.09)\end{array}$ & $\begin{array}{l}5556.17 \\
(18.23)\end{array}$ & $\begin{array}{c}30475.56 \\
\quad(100)\end{array}$ \\
\hline $2012-2013$ & $\begin{array}{c}3850.35 \\
(12.49)\end{array}$ & --- & $\begin{array}{c}4424.18 \\
(14.35)\end{array}$ & $\begin{array}{c}16008.21 \\
(51.92)\end{array}$ & $\begin{array}{l}6549.11 \\
(21.24)\end{array}$ & $\begin{array}{c}30831.85 \\
(100)\end{array}$ \\
\hline 2013-2014 & $\begin{array}{c}2855.95 \\
(9.27)\end{array}$ & --- & $\begin{array}{c}5481.98 \\
(17.79)\end{array}$ & $\begin{array}{c}15200.82 \\
(49.32)\end{array}$ & $\begin{array}{l}7281.75 \\
(23.63)\end{array}$ & $\begin{array}{c}30820.50 \\
(100)\end{array}$ \\
\hline 2014-2015 & $\begin{array}{c}2305.24 \\
(6.98)\end{array}$ & --- & $\begin{array}{c}3192.00 \\
(9.66)\end{array}$ & $\begin{array}{c}17736.37 \\
(53.68)\end{array}$ & $\begin{array}{l}9809.76 \\
(29.69)\end{array}$ & $\begin{array}{c}33043.37 \\
(100)\end{array}$ \\
\hline Minimum & $\begin{array}{l}143.99 \\
(0.37)\end{array}$ & $\begin{array}{c}5830.81 \\
(31.30)\end{array}$ & $\begin{array}{c}3024.12 \\
(8.48)\end{array}$ & $\begin{array}{c}9027.46 \\
(22.51)\end{array}$ & $\begin{array}{c}4292.50 \\
(12.03)\end{array}$ & \\
\hline Maximum & $\begin{array}{c}6415.70 \\
(21.05)\end{array}$ & $\begin{array}{c}22205.61 \\
(55.36)\end{array}$ & $\begin{array}{c}5481.98 \\
(17.79)\end{array}$ & $\begin{array}{c}17736.37 \\
(53.68)\end{array}$ & $\begin{array}{c}9809.76 \\
(29.69)\end{array}$ & \\
\hline Mean I Phase & $\begin{array}{c}365.61 \\
(1.27)\end{array}$ & $\begin{array}{c}13675.75 \\
(47.63)\end{array}$ & $\begin{array}{c}2752.57 \\
(9.59)\end{array}$ & $\begin{array}{c}7773.54 \\
(27.08)\end{array}$ & $\begin{array}{l}4142.82 \\
(14.43)\end{array}$ & \\
\hline Mean II Phase & $\begin{array}{c}3114.25 \\
(9.47)\end{array}$ & $\begin{array}{c}3466.97 \\
(10.55)\end{array}$ & $\begin{array}{c}4404.16 \\
(13.40)\end{array}$ & $\begin{array}{c}14798.11 \\
(45.04)\end{array}$ & $\begin{array}{c}7074.52 \\
(21.53)\end{array}$ & \\
\hline Total Mean & $\begin{array}{c}1739.93 \\
(5.65)\end{array}$ & $\begin{array}{c}8571.36 \\
(27.84)\end{array}$ & $\begin{array}{c}3578.44 \\
(11.62)\end{array}$ & $\begin{array}{c}11285.82 \\
(36.66)\end{array}$ & $\begin{array}{c}5608.67 \\
(18.22)\end{array}$ & \\
\hline SD- Phase I & 0.6142312 & 9.3291934 & 1.1816387 & 4.2237921 & 4.9659813 & \\
\hline SD- Phase II & 7.5942031 & --- & 3.4089397 & 9.9798472 & 5.3559388 & \\
\hline t-value & -2.528 & 0.116 & -2.358 & $3.679^{\star *}$ & -1.959 & \\
\hline
\end{tabular}

Source: Secondary data from annual reports.

Note: ${ }^{*}$ Significant at $1 \%$ level

Figures in brackets represent the percentage share in the total current assets. 
Table 3. Components of current assets as a percentage of total current assets (TSL) for the period from 2005-06 to 2014 - 15 (Rs. in crores)

\begin{tabular}{|c|c|c|c|c|c|c|}
\hline Year & $\begin{array}{c}\text { Cash \&Bank } \\
\text { Balance }\end{array}$ & $\begin{array}{c}\text { Other Bank } \\
\text { Deposits }\end{array}$ & $\begin{array}{l}\text { Sundry } \\
\text { Debtors }\end{array}$ & Inventory & $\begin{array}{c}\text { Current Loans } \\
\text { \& Advances }\end{array}$ & $\begin{array}{c}\text { Total Current } \\
\text { Assets }\end{array}$ \\
\hline 2005-2006 & $\begin{array}{l}288.35 \\
(5.77)\end{array}$ & $\begin{array}{c}0.04 \\
(8.00)\end{array}$ & $\begin{array}{l}539.40 \\
(10.79)\end{array}$ & $\begin{array}{c}2174.75 \\
(43.52)\end{array}$ & $\begin{array}{c}1994.46 \\
(39.91)\end{array}$ & $\begin{array}{c}4997.00 \\
(100)\end{array}$ \\
\hline 2006-2007 & $\begin{array}{l}446.51 \\
(3.04)\end{array}$ & $\begin{array}{c}7234.84 \\
(49.31)\end{array}$ & $\begin{array}{l}631.63 \\
(4.31)\end{array}$ & $\begin{array}{c}2332.98 \\
(15.90)\end{array}$ & $\begin{array}{l}4025.95 \\
(27.43)\end{array}$ & $\begin{array}{l}14671.91 \\
(100)\end{array}$ \\
\hline $2007-2008$ & $\begin{array}{l}465.00 \\
(1.22)\end{array}$ & $\begin{array}{c}0.04 \\
(1.05)\end{array}$ & $\begin{array}{l}543.48 \\
(1.42)\end{array}$ & $\begin{array}{c}2604.98 \\
(6.82)\end{array}$ & $\begin{array}{c}34582.84 \\
(90.53)\end{array}$ & $\begin{array}{c}38196.34 \\
(100)\end{array}$ \\
\hline 2008-2009 & $\begin{array}{l}463.58 \\
(3.99)\end{array}$ & $\begin{array}{c}1127.02 \\
(9.72)\end{array}$ & $\begin{array}{l}635.98 \\
(5.49)\end{array}$ & $\begin{array}{l}3480.47 \\
(30.02)\end{array}$ & $\begin{array}{l}5884.61 \\
(50.77)\end{array}$ & $\begin{array}{c}11591.66 \\
(100)\end{array}$ \\
\hline $2009-2010$ & $\begin{array}{l}500.30 \\
(3.73)\end{array}$ & $\begin{array}{l}2733.84 \\
(20.36)\end{array}$ & $\begin{array}{l}434.83 \\
(3.24)\end{array}$ & $\begin{array}{l}3077.75 \\
(22.93)\end{array}$ & $\begin{array}{l}6678.55 \\
(49.75)\end{array}$ & $\begin{array}{l}13425.27 \\
(100)\end{array}$ \\
\hline 2010-2011 & $\begin{array}{l}4138.78 \\
(16.18)\end{array}$ & - & $\begin{array}{l}424.02 \\
(1.66)\end{array}$ & $\begin{array}{l}3953.76 \\
(15.46)\end{array}$ & $\begin{array}{c}17052.84 \\
(66.69)\end{array}$ & $\begin{array}{l}25569.40 \\
(100)\end{array}$ \\
\hline 2011-2012 & $\begin{array}{l}3946.99 \\
(21.35)\end{array}$ & - & $\begin{array}{l}904.08 \\
(4.89)\end{array}$ & $\begin{array}{l}4858.99 \\
(26.29)\end{array}$ & $\begin{array}{c}8773.73 \\
(47.47)\end{array}$ & $\begin{array}{l}18483.79 \\
(100)\end{array}$ \\
\hline $2012-2013$ & $\begin{array}{l}2218.11 \\
(12.42)\end{array}$ & - & $\begin{array}{l}796.92 \\
(4.46)\end{array}$ & $\begin{array}{l}5257.94 \\
(29.44)\end{array}$ & $\begin{array}{c}9587.82 \\
(53.68)\end{array}$ & $\begin{array}{c}17860.79 \\
(100)\end{array}$ \\
\hline 2013-2014 & $\begin{array}{l}961.16 \\
(7.07)\end{array}$ & - & $\begin{array}{l}770.81 \\
(5.67)\end{array}$ & $\begin{array}{c}6007.81 \\
(44.16)\end{array}$ & $\begin{array}{c}5863.68 \\
(43.10)\end{array}$ & $\begin{array}{c}13603.46 \\
(100)\end{array}$ \\
\hline 2014-2015 & $\begin{array}{l}478.59 \\
(3.36)\end{array}$ & - & $\begin{array}{l}491.46 \\
(3.45)\end{array}$ & $\begin{array}{c}8042.00 \\
(56.52)\end{array}$ & $\begin{array}{c}5215.56 \\
(36.66)\end{array}$ & $\begin{array}{c}14227.61 \\
(100)\end{array}$ \\
\hline Minimum & $\begin{array}{l}465.00 \\
(1.22)\end{array}$ & $\begin{array}{c}0.04 \\
(1.05)\end{array}$ & $\begin{array}{c}543.48 \\
(1.42)\end{array}$ & $\begin{array}{c}2604.98 \\
(6.82)\end{array}$ & $\begin{array}{l}4025.95 \\
(27.43)\end{array}$ & \\
\hline Maximum & $\begin{array}{c}3946.99 \\
(21.35)\end{array}$ & $\begin{array}{c}7234.84 \\
(49.31)\end{array}$ & $\begin{array}{l}539.40 \\
(10.79)\end{array}$ & $\begin{array}{c}8042.00 \\
(56.52)\end{array}$ & $\begin{array}{c}34582.84 \\
(90.53)\end{array}$ & \\
\hline Mean I-Phase & $\begin{array}{l}432.75 \\
(2.61)\end{array}$ & $\begin{array}{c}2219.16 \\
(13.39)\end{array}$ & $\begin{array}{l}557.06 \\
(3.36)\end{array}$ & $\begin{array}{c}2734.19 \\
(16.50)\end{array}$ & $\begin{array}{c}10633.28 \\
(64.15)\end{array}$ & \\
\hline Mean II-Phase & $\begin{array}{c}2348.73 \\
(13.08)\end{array}$ & - & $\begin{array}{l}677.46 \\
(3.77)\end{array}$ & $\begin{array}{l}5624.1 \\
(31.33)\end{array}$ & $\begin{array}{c}9298.73 \\
(51.81)\end{array}$ & \\
\hline Total Mean & $\begin{array}{c}1390.74 \\
(8.06)\end{array}$ & $\begin{array}{c}1109.58 \\
(6.43)\end{array}$ & $\begin{array}{l}617.26 \\
(3.58)\end{array}$ & $\begin{array}{l}4179.14 \\
(24.21)\end{array}$ & $\begin{array}{c}9966.00 \\
(57.73)\end{array}$ & \\
\hline SD Phase I & 1.64647 & 18.9819643 & 3.5405437 & 13.9557056 & 23.66681 & \\
\hline SD Phase II & 7.10251 & --- & 1.5465542 & 16.0751821 & 11.43365 & \\
\hline $\mathrm{t}$-value & -2.608 & --- & 0.593 & -1.107 & 0.184 & \\
\hline
\end{tabular}

Source: Secondary data from annual reports.

Note: Figures in brackets represent percentage share in the total current assets.

A probe into the trends in components of current assets as a percentage of total current assets during the study period as shown in Table 2 has revealed that in case of SAIL, the mean percentage share of cash and bank balance was the least of all components during both the phases, while the mean percentage share of inventory had a phenomenal increase from $27.08 \%$ during the first phase to $45.04 \%$ during the second phase, which was also found to be significant at $1 \%$ level from the t-test. Whereas the difference observed between the two phases in respect of the percentage share of other components was not statistically significant.

In case of TSL as shown in Table 3, out of the total current assets, the mean percentage share of cash and bank balance had scaled up from $2.61 \%$ during the first phase to $13.08 \%$ during the second phase; the mean percentage share of other bank deposits had stood at $13.09 \%$ during the first phase, which however was nil during the second phase, the mean percentage share of sundry debtors had a surge negligibly from $3.36 \%$ during the first phase to 
$3.77 \%$ during the second phase; the mean percentage share of inventory had almost doubled from $16.50 \%$ during the first phase to $31.33 \%$ during the second phase; and the mean percentage share of current loans and advances had considerably declined from $64.15 \%$ during the first phase to $51.81 \%$ during the second phase. However, the t-test exposes that none of the individual components had any significant difference in the percentage share of total current assets during the second phase, since the calculated $\mathrm{t}$-value was less than the table value in respect of all the components.

\section{Zero Working Capital Analysis}

The turnover ratios and the trends in components of current assets analyzed in the earlier sections in respect of SAIL and TSL have exposed that with the increase in net sales, the inventory and debtors were also increasing. At the same time, the cash conversion cycle had stood negative during six out of ten years in case of SAIL and in all the ten years in case of TSL, which therefore necessitates probing whether or not the companies have adopted zero working capital strategy in this section.

The zero working capital analysis of the firms under study has been carried out through the following variables:

i) zero working capital

ii) zero working capital ratio

\subsection{Formula}

Zero Working Capital (ZWC) [14] = Inventories + Debtors (Receivables) - Creditors (payables)
Inventories +

$\begin{array}{ll}\text { Zero Working Capital } & \text { Debtors (receivables) } \\ \text { Ratio (ZWCR) }[14]= & \text { Creditors (payables) }\end{array}$

The zero working capital and the zero working capital ratio of SAIL and TSL are exhibited in Table 4 and 5 respectively during the study period of ten years from 2005-06 to 2014-15.

It is obvious to note from Table 4 that SAIL had not adopted the zero working capital strategy, since the negative values in respect of zero working capital were registered during two years only, i.e., 2009-10 and 2014-15, out of the total ten years of study and correspondingly the zero working capital ratio of these two years were pegged at close to 1 i.e., 0.936 and 0.985 respectively.

In case of TSL, it can be inferred from Table 5 that the company was adopting the strategy of zero working capital throughout the study period, since the negative values were registered in respect of zero working capital in all the ten years by ranging from a low of Rs. $-13179.16 \mathrm{cr}$ to a high of Rs.-1838.24 cr. Consequently, the zero working capital ratios were also pegged at close to zero in all the ten years by ranging from a minimum of 0.340 to a maximum of 0.596 . Hence, the working capital management was efficient.

\section{Impact of Zero Working Capital on Profitability}

To observe the empirical relationship between Zero Working Capital Ratio (ZWCR) and profitability, the Operating Profit Ratio (OPR) and the Return on Capital Employed (ROCE) of the sample companies are taken as

Table 4. Zero Working capital and zero working capital ratio-SAIL for the period from 2005-06 to $2014-15$ (Rs. in crores)

\begin{tabular}{lcccccc}
\hline Year & $\begin{array}{c}\text { Inventory } \\
(\mathbf{1})\end{array}$ & $\begin{array}{c}\text { Debtors } \\
(\mathbf{2})\end{array}$ & $\begin{array}{c}\text { Operational Current } \\
\text { Assets }(\mathbf{1 + 2})(\mathbf{3})\end{array}$ & $\begin{array}{c}\text { Creditors } \\
(4)\end{array}$ & $\begin{array}{c}\text { Zero Working } \\
\text { Capital (3-4) }\end{array}$ & $\begin{array}{c}\text { Zero Working } \\
\text { Capital Ratio(3/4) }\end{array}$ \\
\hline $2005-06$ & 6210.06 & 1881.73 & 8091.79 & 8081.23 & 10.56 & 1.001 \\
$2006-07$ & 6651.47 & 2314.75 & 8966.22 & 8105.99 & 860.23 & 1.106 \\
$2007-08$ & 6857.23 & 3048.12 & 9905.85 & 8960.91 & 944.44 & 1.105 \\
$2008-09$ & 10121.45 & 3024.36 & 13145.81 & 10201.51 & 2944.30 & 1.289 \\
$2009-10$ & 9027.46 & 3493.90 & 12521.36 & 13383.67 & -862.31 & 0.936 \\
$2010-11$ & 11302.79 & 4161.30 & 15464.09 & 13994.33 & 1469.76 & 1.105 \\
$2011-12$ & 13742.37 & 4761.32 & 18503.69 & 14606.26 & 3897.43 & 1.267 \\
$2012-13$ & 16008.21 & 4424.18 & 20432.39 & 14976.39 & 5455.97 & 1.364 \\
$2013-14$ & 15200.82 & 5481.98 & 20682.80 & 19105.61 & 1577.19 & 1.083 \\
$2014-15$ & 17736.37 & 3192.00 & 20928.37 & 21257.32 & -328.95 & 0.985 \\
\hline
\end{tabular}

Source: Secondary data from annual reports 
Table 5. Zero working capital and zero working capital ratio- TSL for the period from 2005-06 to 2014-15 (Rs. in crores)

\begin{tabular}{lcccccc}
\hline Year & $\begin{array}{c}\text { Inventory } \\
(\mathbf{1})\end{array}$ & $\begin{array}{c}\text { Debtors } \\
(\mathbf{2})\end{array}$ & $\begin{array}{c}\text { Operational Current } \\
\text { Assets(1+2)(3) }\end{array}$ & $\begin{array}{c}\text { Creditors } \\
(4)\end{array}$ & $\begin{array}{c}\text { Zero Working } \\
\text { Capital (3-4) }\end{array}$ & $\begin{array}{c}\text { Zero Working } \\
\text { Capital Ratio(3/4) }\end{array}$ \\
\hline $2005-06$ & 2174.75 & 539.40 & 2714.15 & 4552.39 & -1838.24 & 0.596 \\
$2006-07$ & 2332.98 & 631.63 & 2964.61 & 6349.24 & -3384.63 & 0.467 \\
$2007-08$ & 2604.98 & 543.48 & 3148.46 & 6842.26 & -3693.08 & 0.460 \\
$2008-09$ & 3480.47 & 635.98 & 4116.45 & 8965.76 & -4849.31 & 0.459 \\
$2009-10$ & 3077.75 & 434.83 & 3512.58 & 8699.34 & -5186.76 & 0.404 \\
$2010-11$ & 3953.76 & 424.02 & 4377.78 & 12037.59 & -7659.81 & 0.364 \\
$2011-12$ & 4858.99 & 904.08 & 5763.07 & 15958.34 & -10195.27 & 0.361 \\
$2012-13$ & 5257.94 & 796.92 & 6054.86 & 17098.06 & -11043.02 & 0.354 \\
$2013-14$ & 6007.81 & 770.81 & 6778.62 & 19957.78 & -13179.16 & 0.340 \\
$2014-15$ & 8042.00 & 491.46 & 8533.46 & 18251.65 & -9718.19 & 0.468 \\
\hline
\end{tabular}

representative variables of profitability which stand dependent. The simple correlation and regression coefficients with their corresponding tests of significance in respect of SAIL and TSL are shown in Table 6 and 7 respectively.

Table 6 discloses that in case of SAIL, there was no significant relationship between Zero Working Capital Ratio and that of both the Operating Profit Ratio and the Return on Capital Employed during the study period holding good the null hypothesis.

It is evident from Table 7 that in case of TSL, though there was no significant relationship between Zero Working Capital Ratio and Operating Profit Ratio, however, there was a significant relationship between Zero Working Capital Ratio and the overall profitability, namely, Return on Capital Employed during the study period. In fact, the correlation coefficient between Zero Working Capital Ratio and Return on Capital Employed was as high as 0.8006 , which was statistically significant at 0.01 level. Further, the regression analysis has revealed that the coefficient of determination R Square denoting the variation explained by the independent variable- Zero Working Capital Ratio was 0.641, which was also statistically significant at 0.01 level and hence the null hypothesis is rejected. This means that the Zero Working Capital Ratio has impacted to the tune of $64.1 \%$ on the variability of the Return on Capital Employed by its linear relationship in case of TSL.

\section{Key Findings}

- Both the Current and Liquid Ratios were below the standard norms of 2: 1 and 1: 1 [17, 18] respectively for both SAIL and TSL during the study period with
Table 6. Impact of ZWCR on OPR and ROCE-

SAIL, Correlation and regression summary

\begin{tabular}{lccc}
\hline Year & ZWCR & \multicolumn{2}{c}{ Dependent Variables } \\
\cline { 2 - 4 } & & OPR & ROCE \\
\hline $2005-06$ & 1.001 & 20.310 & 36.541 \\
$2006-07$ & 1.106 & 25.489 & 45.473 \\
$2007-08$ & 1.105 & 25.458 & 44.898 \\
$2008-09$ & 1.289 & 18.014 & 27.341 \\
$2009-10$ & 0.936 & 23.208 & 21.292 \\
$2010-11$ & 1.105 & 16.480 & 13.425 \\
$2011-12$ & 1.267 & 22.666 & 10.674 \\
$2012-13$ & 1.364 & 22.000 & 6.379 \\
$2013-14$ & 1.083 & 20.710 & 6.263 \\
2014-15 & 0.985 & 23.630 & 5.316 \\
r & & -0.2076 & -0.1921 \\
t-value & & -0.6002 & -0.5535 \\
R & & 0.208 & 0.192 \\
R Square & & 0.043 & 0.037 \\
Adjusted R Square & -0.077 & -0.084 \\
F & & 0.360 & 0.306 \\
Sig. & & 0.565 & 0.595 \\
S/ NS & & NS & NS \\
\hline Source: Computed from secondary data S: Significant NS: Not Significant \\
Independent Variable: ZWCR & &
\end{tabular}

further decline during the second phase, which however was not statistically significant.

- The decline in the Inventory Turnover and the Creditors' Turnover Ratios during the second phase for both the firms was found to be statistically significant.

- With regard to Debtors' Turnover Ratio, SAIL had registered a decline during the second phase, which was 
Table 7. Impact of ZWCR on OPR and ROCETSL, Correlation and regression summary

\begin{tabular}{lccc}
\hline \multirow{2}{*}{ Year } & ZWCR & \multicolumn{2}{c}{ Dependent Variables } \\
\cline { 2 - 4 } & & OPR & ROCE \\
\hline $2005-2006$ & 0.596 & 42.947 & 44.078 \\
$2006-2007$ & 0.467 & 42.880 & 27.437 \\
$2007-2008$ & 0.460 & 46.292 & 17.643 \\
$2008-2009$ & 0.459 & 41.124 & 15.545 \\
$2009-2010$ & 0.404 & 39.560 & 14.523 \\
$2010-2011$ & 0.364 & 58.962 & 15.751 \\
$2011-2012$ & 0.361 & 56.580 & 15.440 \\
$2012-2013$ & 0.354 & 52.524 & 11.974 \\
$2013-2014$ & 0.340 & 54.612 & 13.216 \\
2014-2015 & 0.468 & 49.114 & 11.289 \\
r & & -0.6657 & $0.8006^{* *}$ \\
t-value & & -2.5232 & $3.7790^{* *}$ \\
R & & 0.666 & 0.801 \\
R Square & & 0.443 & 0.641 \\
Adjusted R Square & & 0.374 & 0.596 \\
F & & 6.367 & 14.281 \\
Sig. & & 0.036 & $0.005^{* *}$ \\
S/ NS & & $\mathrm{NS}$ & $\mathrm{S}$ \\
\hline SorceCong & & &
\end{tabular}

Source: Computed from secondary data S: Significant NS: Not Significant

Independent Variable: ZWCR ** Significant at 0.01 level

statistically significant, while for TSL it was gliding up and however was not statistically significant. Hence all these confirm a low liquidity experienced by both the sample firms.

- Further, the Cash Conversion Cycle (CCC) reveals a spontaneous management of working capital requirements by both the firms, as it was negative (Gross Operating Cycle less than the Creditors Payment Period) totally during six years in case of SAIL and in all the ten years of study period for TSL. The decline in CCC during the second phase registered by TSL was also statistically significant.

- On the score of Components of Current Assets as a Percentage of Total Current Assets, none other than inventory had any significant difference during the second phase in case of SAIL, which particularly was increasing, while for TSL none of the individual components had any significant difference in the percentage share of total current assets during the second phase.

- With regard to the traces of Zero Working Capital, the Zero Working Capital Ratio (ZWCR) in case of SAIL confirms that the firm had not adopted the Zero Working Capital Strategy, while in case of TSL it was found to be adopted consistently throughout the study period, since its ZWCR was pegged at close to zero in all the years and therefore its working capital management was efficient. At the same time, the ZWCR in case of TSL had also impacted significantly its overall profitability, i.e. Return on Capital Employed, which actually was declining.

\section{Conclusion}

The steel industry is one of the most essential industries in India which augments the industrial development by stimulating all other sectors like construction, manufacturing, transportation, automobiles and so on. Studying the trends in working capital management and the adoption of the concept of zero working capital along with its impact on profitability in SAIL and TSL have divulged that unlike SAIL, TSL was adopting zero working capital consistently throughout the study period and has impacted significantly on the variability of its Return on Capital Employed. This, however, could be continued without straining the relationship with creditors.

\section{References}

1. Pandey, I.M. Essentials of Financial Management. UP: Vikas Publishing House Pvt. Ltd, 2014. pp. 441.

2. "Tata Steel's UK Unit Sale Process Begins on Monday", Times Business, The Times of India, Coimbatore, April 8, 2016. pp. 13. Available: Reeba.Zachariah@timesgroup.com

3. Eljelly, A. "Liquidity-Profitability Tradeoff: An Empirical Investigation in an Emerging Market", International Journal of Commerce and Management, vol. 14(2), pp. 48-61, 2004. Available: www.researchgate.net

4. Padachi, K. “Trends in Working Capital Management and its Impact on Firms' Performance: An Analysis of Mauritian Small Manufacturing Firms", International Review of Business Research Papers, vol. 2(2), pp. 45-58, 2006. Available: www. bizresearchpapers.com

5. Gill, B. \& Mathur. "The Relationship between Working Capital Management and Profitability: Evidence from the United States", Business and Economics Journal, vol. 1, pp. 1-9, 2010. Available: www.astonjournal.com/bej.html

6. Niranjan, M., et al. "Impact of Working Capital Management on Liquidity, Profitability and Non-Insurable Risk and Uncertainty Bearing : A Case Study of Oil and Natural Gas Commission (ONGC)", Great Lakes Herald, vol. 4(2), pp. 21-42, 2010. Available: www.greatlakes.edu.in

7. Raheman, A., et al. "Working Capital Management and Corporate Performance of Manufacturing Sector in Pakistan", International Research Journal of Finance and Economics (IRJFE), (47), pp. 151-163, 2010. 
8. Jain, P.K., et al. "Working Capital Management of Reliance Industries Limited: A Case Study", Journal of Accounting and Finance, vol. 25(2), pp. 3-16, 2011.

9. Abuzayed, B. "Working Capital Management and Firms' Performance in Emerging Markets: The Case of Jordan", International Journal of Managerial Finance, vol. 8(2), pp. 155-179, 2012. Available: www.emeraldinsight.com

10. Makori, D.M. \& Jagongo, A. "Working Capital Management and Firm Profitability: Empirical Evidence from Manufacturing and Construction Firms Listed on Nairobi Securities Exchange, Kenya", International Journal of Accounting and Taxation, vol. 1(1), pp. 1-14, 2013. Available: www.aripd.org/ijat
11. Naveen, Ch. "Working Capital Management of GlaxoSmithKline Consumer Health Care: An Empirical Study", IPE Journal of Management, vol. 4(2), pp. 106-118, 2014.

12. Niranjan, M., et al., op.cit., p.23

13. Gupta, S.P. Statistical Methods. New Delhi: Sultan Chand and Sons, 2007. pp. 181, 289.

14. Naveen, Ch., op.cit., p.114

15. Gupta, S.P., op. cit., p.916

16. Ibid., p.391, p.441, p.923, p.1006

17. Pandey, I.M., op.cit., p.419

18. Gupta, R.L., \& Radhaswamy, M. Advanced Accountancy. New Delhi: Sultan Chand and Sons, 2003. p. VI.2.13 